\title{
1. Introduction: intellectual property on the line
}

In a provocative speech at Harvard University's Berkman Center in Cambridge Eben Moglen likened the fight for free software to the civil rights movement. The Columbia University professor wants to liberate software and other forms of information from the clutches of companies like Microsoft, the Hollywood 'culture vultures', and the greedy 'telecom oligopolists'. He proposes 'anarchism' as a better mode of software production. Moglen is equally concerned about the general lockdown on 'creative, communal resources'. In his eyes, there is something 'morally repugnant' about intellectual property rights. ${ }^{1}$ Thus, for Moglen and many others, the stakes in emancipating content from the thralldom of property protection couldn't be higher - nothing less than the 'perfectibility of humankind'. ${ }^{2}$

While Moglen's philosophy may sound extreme even to some of those who support the Free Software movement, it typifies the anti-property rhetoric that has escalated dramatically over the last two decades. Headlines such as 'Creativity in Chains' and 'The Tyranny of Copyright' are now commonplace even in the popular media. Scholarly articles attack intellectual property rights as unjust monopolies or even as 'restriction[s] on the liberty of everyone' (Palmer 1990, p. 831). Conferences with intimidating names like 'Knowledge Held Captive' have become fairly commonplace in academia. Books such as Free Culture by Lessig (2004), Copyrights and Copywrongs: The Rise of Intellectual Property and How it Threatens Creativity by Vaidhyanathan (2001), Owning the Future by Shulman (1999), or Steal This Idea: Intellectual Property Rights and the Corporate Confiscation of Creativity by Perelman (2002) develop sharp indictments of the current intellectual property regime. Consider Perelman's (2002) dire warning that this regime 'represents a serious threat to both scientific and technological progress'. Or Shulman's (1999) concern about a coming 'meltdown' in the software industry due to the omnipresence of software patents (p.70).

The motto adopted by some of those who believe that intellectual property should no longer be an entitlement is simple and unambiguous: 'information should be free'. For Barlow (1994), who has propagated this message relentlessly, information is akin to a self-replicating life form that should not be constrained. Since legal protection for intellectual property is inconsistent with this normative claim, such protection is illegitimate. 
It is not surprising, therefore, that 'intellectual property' has become a term of opprobrium among some in the academy, especially at major law schools, since it evokes the specter of unjust enrichment for greedy corporations and the suppression of free speech by large media oligopolies. This groundless enclosure of intellectual objects is now a great cause célèbre among many scholars, who talk frequently about the perils of 'patent thickets', the tragedy of the 'anticommons', the 'demonization of piracy', and the dominance of the 'property' paradigm in the public psyche. There is a sense of urgency about this epic battle to save our culture. We are told that the copyright 'wars', including the music industry's recent efforts to protect its content, are the equivalent of the new 'Homeric tragedies' (Lessig 2002).

In light of this enclosure movement, some scholars call for a radical revision of the law in order to narrow the scope of intellectual property rights. Others go further and attempt to undermine the assumptions underlying those rights by deconstructing the conventional idea of authorship along with correlative notions such as genius and originality. With these traditional notions out of the way exclusive property rights, at least in their current form, will simply collapse. Property implies a reified, stable text, but, according to deconstructionists, every text can be liquidated into its shadow along with its creator.

To be sure, certain excesses have worked their way into intellectual property law and everyone in this field has his or her favorite 'copyright horror story'. One of the reasons behind this anti-property rhetoric is the unnecessary expansion of rights, thanks in part to the ability of those 'culture vultures' to capture an impressionable Congress. The breadth and duration of copyright entitlements have been extended for questionable purposes and the case for certain reforms is compelling. More and more objects are eligible for a patent, which is awarded too easily. Trademark rights have also broadened in scope. But is intellectual property itself really an anachronism? Has the copyright, which dates back to the Statute of Anne in early eighteenth century England, outlived its usefulness in this dynamic digital era? Has this right become merely another potent weapon in the arsenal of avaricious corporations? Or are such rights still necessary for the purpose of stimulating innovation? And are they consistent with the norms of justice?

Our primary purpose in this book is to answer the last two questions in the affirmative. We admit, however, that intellectual property law has overreached in recent years. Some legislation such as the Copyright Term Extension Act (CTEA), which extended copyright protection for an additional 20 years, has gone too far. The scope of patent protection is too broad, and as a result many dubious patents have been approved to the detriment of real innovation. Is it really necessary to have patents for trivial innovations such as the 'Buy it now feature' used by eBay ? $^{3}$ In addition, there must be a broader interpretation of compulsory licensing so that a patent can be suspended if it prevents life-saving 
medication from reaching those in developing countries. Finally, while some commercialized cultural objects deserve stability of meaning, there has been an unwarranted expansion of trademark dilution doctrine. This has made it more difficult for individuals to offer critical or parodic commentary about a brand or trademark. For example, anti-cybersquatting legislation known as the Anticybersquatting Consumer Protection Act (ACPA) clearly broadens the application of trademark infringement. This new law equips trademark owners with the ability to pursue claims against domain names that are similar to or dilutive of their trademarks, including domain names that offer a critique of a particular trademark (such as 'wal-martsucks.com'). ${ }^{4}$

There is also concern about policies such as the Digital Millennium Copyright Act (DMCA, 1998) that presumably undermine the balance in intellectual property law between content creators and consumers. Digital technology makes it much easier to reproduce, distribute, and publish information. But thanks to code in the form of digital rights architectures, it is also possible to control or enclose digital information to a degree never before possible. When buttressed by laws such as the DMCA that forbid circumvention of these protection systems, the digital content becomes tightly sealed. Rights management systems give content providers the ability to define what rights users will have to use, copy, or edit a work which they have purchased. ${ }^{5}$ Code becomes the new enforcer of property rights and that code need not honor copyright's internal safety valves such as fair use or first sale.

But the answer to these problems is not to dismantle or radically overhaul the whole system. Nor is it to jettison traditional concepts of authorship and originality in a post-modern conceptual frenzy. Rather, it is to concentrate on finding the right balance, to re-calibrate the requisite measure of legal protection so that authors and creators are justly rewarded and future innovation stimulated, without impediments to the vitality of the intellectual commons or the free flow of knowledge and information. Boundaries need to be reconfigured without making copyright so thin that authors cannot control the meaning of their works nor appropriate their economic value.

Thus, our main objective in this book is simply to reinforce the center and to demonstrate the need for balanced intellectual property rights as a matter of economic pragmatism, but primarily as a requirement of natural law and justice. Our focus is far more theoretical than practical. We believe that reinforcement of traditional theory is necessary, however, given the growing movement against copyright along with the prevalence of anti-property rhetoric, idealistic talk about collective ownership, and renewed demands for the dilution of author's rights. But while this rhetoric is sometimes hyperbolic, it is not all hype. There has been an unhealthy trend to expand intellectual property rights without an adequate normative justification, and so the need for balance and reform must not be understated. 
In this introductory chapter we provide a cursory overview of the main axis of discussion in this book. Before we can defend intellectual property rights we must review their long history along with the current legal regime in the Western world. That history shows a consistent sensitivity to natural justice issues and the need to safeguard creative works from free riders. An understanding of history is particularly important. Contrary to recent claims, copyright has been understood as property for over 200 years.

Our narrative then concentrates attention on the principal reasons behind the sustained assault against intellectual property rights. As we will see, some of these reasons are valid, but many represent exaggerated contentions about the dangers of exclusive property rights in this post-modern world that questions the very notion of 'individual' rights. Once we perceive the spuriousness of most post-modern arguments against the traditional notions of property, authorship, and originality, and re-focus on the author's legitimate interests, we can defend an author-based entitlement that is fair and measured.

\section{RESCUING AUTHORS AND THEIR PROPERTY RIGHTS}

The term 'intellectual property' refers to patents, copyrights, trademarks, and trade secrets. According to Lemley (1997, p. 895), 'patent and copyright law have been around in the United States since its origin, but only recently has the term "intellectual property" come into vogue'. ${ }^{6}$ Similarly, Vaidhyanathan (2001, p.11) refers to the term intellectual property as 'fairly young'. However, this historical account is inaccurate. Hughes (2006) thoroughly documents how courts and legislatures regularly characterized copyright as works of property. He cites the use of the term 'intellectual property' in Davoll v. Brown' in 1845 and Mitchell v. Tilghman ${ }^{8}$ in 1873. In the former case the Court refers to intellectual property as 'the labors of the mind', which are 'as much a man's own ... as what he cultivates, or the flocks he rears' (p. 199). Hughes also cites other sources such as Van Dyke's 1888 treatise calling for the extension of copyright to foreign authors where the term 'intellectual property' was used without 'initial discussion or definition' because it was taken for granted that the readers were familiar with this phrase (Hughes 2006, p. 1006). As we will see in the next chapter, the antecedents in European jurisprudence for the use of this term are also quite extensive.

Thus, intellectual property was not a foreign concept until several decades ago. For 200 years copyright has been described as 'artistic property', 'literary property', and now as intellectual property (Hughes 2006, p. 1083). ${ }^{9}$ The purpose of intellectual property law has always been to safeguard the integrity of intellectual objects, which are quite different from physical objects because they are 
not subject to scarcity. There are practical limitations to the number of physical objects one can own or reproduce, but the same can usually not be said about intangible forms of property. Laws that establish and protect intellectual property rights create artificial scarcity, and hence they require some justification from both an ethical and economic viewpoint (Cornish 2004). The focus of this treatise is to provide a fresh look at the former justification for creating such a scarcity.

The assault on intellectual property rights has come from several different directions. Critics of the current intellectual property regime often point to the damage done to the intellectual commons by privatization. According to Opderbeck (2004, p. 201), the 'commons' metaphor has achieved the status of a 'meta-narrative for all debates about proprietary rights'. This intellectual commons includes ideas, concepts, theories, scientific or research methods, scientific principles, mathematical algorithms, laws of nature, words, names, symbols, and so on. It also includes works of literature, music, or art, whose copyright protection has expired. In normative terms, this domain is commonly regarded as a space that should be open to everyone, given its importance for free speech rights. Of course, open access to this domain is also important to ensure future innovation and the evolution of technology. Hence the problem with enclosing or individuating the commons, and thereby depriving others of the raw material they need for their own creative endeavors.

A second problem for exclusive property rights is the general trend against supporting individual rights. Our attachment to individual property rights is interpreted as symptomatic of the individualism at the core of Western society that needs reappraisal and deconstruction. ${ }^{10}$ On the other hand, collectivist approaches to free speech, property, and privacy rights are now quite commonplace. Often this type of collectivist theory is predicated on a rejection of the idea that people are really autonomous. When this premise is denied, legal regimes dedicated to preserving autonomy are destabilized. In this context, classical notions of 'private' property and free speech rights become difficult to validate. Tushnet (2004), for example, claims that the current model of free speech in the US is far too individualistic and so courts are too fixated 'on the individual on his soapbox' (p.567). Advocates of collectivist theory often seek to improve democratic speech by stifling or restricting the speech of those with disproportionate power such as media conglomerates. ${ }^{11}$ The control of culture, they contend, is too concentrated in the hands of big media companies who exercise excessive control over 'meaning-making processes' (Elkin-Koren 1994, p. 399).

Along these same lines, some legal scholars want to subordinate an individual's interests in his or her intellectual property to the needs of the 'collective', such as the public good represented by the intellectual commons. Intellectual property rights are pejoratively categorized as a form of 'possessive individualism' which has given rise to many of the worst abuses of capitalism. ${ }^{12}$ 
We are encouraged to regard property, privacy, or speech as 'social values' rather than support the idea that they are individual entitlements or natural rights. Proponents of this thesis argue that 'normative individualism' is simply an outmoded way to understand property rights issues. They contend that the narrow conception of an individual property right provides an insufficient framework for formulating sound public policy that promotes the social good. Since Locke's philosophy is 'a celebration of the individual, the unencumbered and autonomous human being', it is no surprise that his arguments on behalf of exclusive property rights have been so discredited (Borgmann 1992, p. 25). According to this school of criticism, Lockean individualism, along with the system of individual natural rights which it undergirds, needs to be reconceptualized in light of new economic and social realities.

The justification of intellectual property rights has also been undermined by many intellectual forces, but in particular by recent post-modern scholarship, which has expressed doubts about the source and originality of intellectual objects. There are clear echoes of Marx in the writings of some post-modernists who describe a crisis of human subjectivity and who see the structures of social and economic domination inscribed in that human subject. The assumption had always been that the correlate of the creative work (such as the novel or poem) was the creative subject, who was responsible for his or her work. But critics argue that it is arbitrary to assume that this isolated, Lockean subject is the ultimate responsible source of the work. Why not revert to something more primordial such as social or communal sources, which have so heavily influenced the authorial subject?

The most radical alternative to intellectual property rights is to establish a regime where all intellectual products remain unowned, by either individuals or organizations. Language, for example, can be freely used by anyone, and the results of most scientific research is public knowledge. Proponents of this view, which we might label 'information socialism', argue that the elimination or radical curtailment of intellectual property rights will lead to the expansion of the intellectual commons and the fostering of creativity. It will also engender 'greater political and economic equality' (Martin 1998, p.311). Along these same lines, Rifkin (2000) describes this new millennium as an 'age of access' where access to information and digital networks takes precedence over individual property rights. Those who oppose patents for the results of scientific research claim that the norm for such research should be 'communism' so that scientific advances are the product of the community. ${ }^{13}$ Other critics of intellectual property rights resist such solutions. Rather, they simply believe that intellectual property rights have become too strong and broad, and therefore need significant adjustment.

There are several reasons for being hesitant about overthrowing the traditional intellectual property rights regime. First, a strong property right is 
justified for social welfare reasons - it is still necessary to induce innovation and to expedite the most productive organization of economic activity. Even Thomas Jefferson, who is often lionized for his anti-intellectual property convictions, admitted that 'an exclusive right' to the returns from one's invention will most likely be 'an encouragement to men to pursue ideas which may produce utility' (Hughes 2006, p. 1030). The courts have often underscored this economic orientation of intellectual property rights in their decisions about copyright or patent protection. There is evidence that property rights have a dynamic incentive effect and are necessary to promote progress, especially in discrete industries such as pharmaceuticals, chemicals, and medical equipment. ${ }^{14}$ Alternatives to patents such as government-awarded prizes seem unworkable. As Jaffe and Lerner (2004) point out, if the government tried to reward innovation with prizes it would often fail to set the right amount, whereas patents by their nature are 'proportional to the size of the discovery' (p. 39).

Even if we grant the need for patents in certain industries such as pharmaceuticals, what about the necessity of patent protection for products like software? Patents for software applications (excluding their underlying algorithms) were validated in several landmark court cases such as Diamond $v$. Diehr. ${ }^{15}$ They have been rebuked in recent years, however, especially by the advocates of open source code. Moglen (2003, p. 112) has argued with some insistence that programmers do not need incentives to write software. The idea of 'incentives', he contends, is a 'pretty crummy' metaphor for describing human creative activity. In his view, if we can adapt technology and change our social structures it will be possible to bring creative people together who will produce software without the need of exclusive property rights. We will address this question in later chapters, but let it suffice to say that it's certainly questionable whether or not the 'gift culture' envisioned by those in the open source movement is a viable substitute for market-based incentives.

Western societies, of course, have provided an ample level of intellectual property protection in order to promote future innovation and creativity. They have tended to presume that without such protection creators would not always be able to recover their initial investment, and thus would refrain from creative activity. If society wants big-budget epic movies and expensive technological innovation, it will have to protect those items from free riders. Precisely how that level of protection is calibrated in order to maximize productivity, however, is a matter of interminable debate. But it is difficult to argue with the results. Software companies in the United States typically spend billions of dollars each year on research and development, thanks in part to the fact that they can count on some sort of intellectual property protection for their inventions. The US pharmaceutical industry invests about $\$ 40$ billion a year to develop new drugs thanks to the stimulus provided by a patent. ${ }^{16}$ 
There are many commentators who grudgingly admit the need for intellectual property rights for these pragmatic, economic reasons. These rights, they acknowledge, are a 'necessary evil', because they restrict the free flow of information, but they are required to encourage investment in innovation. ${ }^{17}$ This rationale, however, hardly provides a strong enough foundation for a 'right'. Nor has this rationale been the driving force behind the evolution of intellectual property rights (see Chapter 2). When rights are contingent solely on maximizing the social good, those rights tend to be thin and tentative, with limited scope. They are also more apt to be subject to arbitrary restrictions based on some utilitarian calculus. ${ }^{18}$ Moreover, as Yen (1990, p.558) points out, 'economics alone cannot serve as copyright's normative touchstone' because of the problems involved in defining and measuring society's welfare.

Our primary line of reasoning is that an exclusive intellectual property right is not just a necessary evil, required and tolerated as a stimulus for productive innovation. Rather, this right is also deserved as a matter of justice - creators have a moral entitlement to capture substantial value from their creative, original work, so long as there is no exhaustion of common resources and no trampling upon the right of others to do the same. Authors also have a right to control the integrity of their works, at least for a limited amount of time.

In order to make a morally persuasive case, it is essential that we retrieve a sensible notion of authorship and clarify the meaning of concepts such as originality and creativity which have been called into question. We must directly impugn the deconstructionist vision of the author as a participant in a process rather than as the source of a creative work. Otherwise it becomes unintelligible to talk in terms of an author-based entitlement. As Goldstein (1991) observed, 'Copyright, in a word, is about authorship' (p. 110). Hence we will try to demonstrate that many of the arguments undermining individual authorship or redefining the author as a 'participant' are illogical and rest on questionable assumptions about human nature.

Once we clear the obstacles we turn to the task of constructing a coherent theory of property rights. By orchestrating the texts of Fichte, Locke, and Hegel we can defend the case for an author's moral right to appropriate the value of his or her creative expression. An exclusive intellectual property right, ultimately grounded in each person's self-dominion, is a just entitlement as long as it rewards the creator without causing direct harm to the intellectual commons. Locke's theory is especially helpful in reconciling strong intellectual property rights with a commons composed of intangible goods.

Hence our analysis will rely most heavily on Locke, whose classical discourse on property rights still resonates several centuries after the composition of the Two Treatises of Government. Key Lockean arguments will be invoked to present a convincing case for a natural intellectual property right under certain conditions. We also turn to Hegel's theory for support because of its 
emphasis on how property rights enhance an author's personhood interests in her work.

This moral or non-economic argument for intellectual property rights begins with a reaffirmation of Locke's insight that the creator or author has the foundation of a property right within herself in the form of the personal labor that she performs. If labor is mine it is logical to assume that what I make with that labor is also mine. Locke's primitive articulation of these ideas is not lost on many later thinkers from diverse sources who have reflected about the need for individual property rights. Even those who reject Locke's anthropological premise of atomistic individualism recognize the cogency of the labor theory of ownership. In his encyclical Centesimus Annus, the 'philosopher-pope', John Paul II, enthusiastically embraced that theory.

Traditional readings of Locke emphasize his claim that a property right is engendered by 'mixing' this valuable labor and skill with something that is held in common. While the mixing metaphor has been confusing, Locke is simply saying that purposeful labor is appropriative so long as certain conditions are met and the granting of the property right causes no harm. These conditions are captured in Locke's famous proviso. Creators too deserve a property right in their original works. An author or inventor who invests his or her time, energy, skill, and personality in a creative, original project surely has an abiding and 'morally significant' interest in the end result (Himma 2007). ${ }^{19}$ This entitlement is a simple matter of fairness. If we accept the argument that the creator has a morally significant interest in his or her work, it should logically follow that the creator has a presumptive claim to its appropriation, so long as no one else is injured by the recognition of this claim.

This argument presumes that any appropriation of abstract ideas or the intellectual 'raw materials' used to construct a creative project is not legitimate. In the case of intellectual or ideal objects meeting this condition is usually not as problematic as it is when material goods are at stake. Thus, Locke's theory actually fits better with intellectual property. Developing creative expression that borrows from ideas in the 'intellectual commons' does not deplete the commons, since consumption or use of those ideas is non-rivalrous. Rather, it conserves those ideas as valuable inputs for others to use. The virtual appropriation of newly created intellectual objects does not harm the other commoners, so they have no reason to complain. In Locke's language intellectual property rights (which he does not explicitly consider) do not 'entrench upon the right of another' (1988, II: $\S 36$ ). On the contrary, with abstract ideas protected, and the new work disclosed for all to see and utilize in a limited way, society actually benefits from this enlargement of the commons.

With Locke's theory in mind we will argue that information socialism, where all intellectual objects are commonly owned, is an impractical and unworkable alternative to the current system. But we also contend that rigid information 
capitalism, which denigrates the value of the intellectual commons and promotes 'hyper-thick' protections such as a perpetual copyright, is also misguided. The information capitalist (as we conceive the term) favors absolute property rights and rejects the principle of just distribution embodied in Locke's proviso.

Instead, what's necessary is a prudent level of protection that approximates the ideal of the Aristotelian mean. Accordingly, property rights must be measured and proportionate to an author's need both to appropriate a fair portion of the value of his work and to protect that work's integrity within a limited time frame. Those legal rights should also be structured to help induce future creative effort. Property rights, properly configured, should mediate two polarities. One polarity overemphasizes the exclusive, private ownership of intellectual objects, while the other polarity is represented by the radical viewpoint that all intellectual objects should be collectively or jointly owned.

As we examine some of the myths about the supposed evils of intellectual property rights, we will see that the fixation on 'control' and 'enclosure' is exaggerated, since perfect control of information is impossible. Positive externalities from published works abound whether authors like it or not. At the same time, flawed legislation such as the DMCA and particularly the CTEA reminds us that policy makers are subject to capture. This has led to the unwarranted expansion of intellectual property rights that is not in the public interest. In their zeal to thwart piracy and to protect fragile digital content there is also a threat that content providers will insist on greater control than the intellectual property system has tolerated in the past. Policy makers must find that elusive middle way that balances legitimate concerns about protecting intellectual objects with the need to preserve a rich substrate of common information resources.

We admit that discerning and legislating the 'right' or proportionate amount of intellectual property protection is a difficult process. But we will offer and defend some recommendations in the course of this analysis: shorter duration for copyright protection, more limited scope of patent coverage, thick patent protection only for genuine inventions that are costly to commercialize, responsible deployment of architectural constraints protecting digital content, and so forth.

Balanced intellectual property rights are one of the key foundations for a just and free society, as Abraham Lincoln and other leaders have clearly appreciated. In Lincoln's words, they add 'the fuel of interest to the fire of genius', and thereby encourage investment in the production of intellectual objects and expressive works. ${ }^{20}$ Also they help to preserve the logical connection between a work and its author or inventor. If we subvert the traditional notion of authorship, it becomes increasingly difficult to allocate accountability or to fix responsibility for intellectual objects. And if we impose on the author the burden of responsibility for his or her creative work, it is only fair that the author should be able to reap its rewards as well. 
Finally, these rights are critically important for autonomy. Hegel underscored the link between property and freedom, and that theme will thread its way through this book. An author should have the right to exercise some control over his or her creative expression, especially since that expression is an extension of the author's personality. An exclusive property right represents a decentralized incentive system, which gives authors and inventors the ability to control how their works will be utilized and distributed. In our estimation, it is preferable to alternatives such as a centralized subsidy system managed by the state. Moreover, a regime of information socialism or collective ownership would be unfair to creators and inventors, who would lose the ability to control the integrity of their work. As Hughes (1999) convincingly demonstrates, listeners and passive non-owners also have an interest in the stability of meaning of cultural objects enabled by durable intellectual property rights.

There is an old medieval adage which captures the spirit of this book written in general support of intellectual property rights theory: abusus non tollit usum or 'abuse does not abolish rightful use'. There are abuses in intellectual property law and those abuses should be swiftly corrected. But the presence of abuse should not interfere with the preservation of reasonable intellectual property rights that fairly reward authors and protect their ability to safeguard the integrity of their works.

\section{NOTES}

1. This claim appears in Moglen's (2002) essay called 'Anarchism Triumphant' (p. 123).

2. See Moglen (2003) for additional commentary on these views.

3. This business method patent case has gone all the way to the US Supreme Court. See eBay v. MercExchange, L.L.C. 547 U.S. 388 (2006).

4. In November, 1999 Congress passed the Anti-Cybersquatting Consumer Protection Act (ACPA) as an amendment to the Lanham Act or Federal Trademark Dilution Act (Section 1125(d)). The ACPA expressly prohibits 'cybersquatting' or other forms of domain name speculation. The paradigmatic cybersquatter seeks to register domain names in bad faith in order to extort a trademark owner. In other cases, however, while there is no extortionate behavior, there appears to be some form of abuse. These abuses can include the engendering of pre-sales confusion which can occur if users are misled about the origin of goods sold at a particular web site (often called 'initial interest confusion'). Thanks to the ACPA, trademark holders can file suit against domain name registrants who have allegedly misappropriated their trade name or a name that is 'confusingly similar' to their mark. See also Bally Total Fitness Holding Corp v. Faber, 29 F. Supp. 2d (1998) [C.D. Cal].

5. See Ku (2002).

6. Cornish (2004) points out that the use of this term became common in the 1960s once the United Nations created the World Intellectual Property Organization or WIPO (see pp. 2-3). References to intellectual property appeared prior to the establishment of WIPO, but according to Lemley (1997), these previous uses 'do not seem to have reflected a unified property-based approach to the separate doctrines of patent, trademark, and copyright ...' (p. 896). It is indisputable, however, that copyrights and patents were understood as 'property' well before this time.

7. 7 F. Cas. 197 (C.C.D.Mass.). 
8. In Mitchell v. Tilghman 86 U.S. (19 Wall.) 287 (1873) the US Supreme Court referred to intellectual property for the first time in its opinions.

9. See, for example, Wheaton v. Peters, 33 U.S. (8 Pet.) 591 (1834) where the Court held that 'law reports, like other books, are objects of literary property' (p. 612) and Brady v. Daly, 175 U.S. 148 (1899), where the court refers to the protection of 'dramatic literary property' (p. 157).

10. According to Chon (1996, p. 274), 'even in intensely collaborative environments, individual feelings of ownership (or perhaps possessiveness) emerge'.

11. For the most part, however, US courts have not yet been amenable to this radical re-interpretation of the First Amendment. See Buckley v. Valeo, 424 U.S. 1 (1976) where the Supreme Court rejected the idea that 'government may restrict the speech of some elements of society in order to enhance the relative voice of others' as incompatible with the First Amendment (p.49). On the other hand, see Austin v. Michigan Chamber of Commerce, 494 U.S. 652 (1990).

12. See Ryan's (1984) discussion on this topic in Political Theory of Property (pp. 163-4). See also Rasmussen's (2001) article called 'Why Individual Rights'.

13. For a discussion of this position see Kieff (2001), especially pp.691-7. This article is a reaction to an article by Rai (1999) highlighting the negative impact of patents on the prescriptive norms of scientific research.

14. The story is a bit different, however, in complex industries such as semiconductors and computers. See a summary of recent studies in 'Patently Absurd' (2001).

15. 450 U.S. 175 (1981).

16. For example, Pfizer's annual research budget is $\$ 7$ billion, the highest in the industry. See Martinez and Goldstein (2007).

17. The idea that intellectual property rights are a 'necessary evil' has a long and distinguished pedigree. Lord Macaulay (1906) described copyright in the same bleak terms: 'For the sake of the good we must submit to the evil. But the evil ought not to last a day longer than is necessary for the purpose of securing the good' (pp. 203-204).

18. Skeptical supporters of intellectual property rights on utilitarian grounds argue that those rights should be quite constricted: 'copyright holders should receive only such incentives as are necessary to impel them to create and disseminate new works' (Litman 1996, pp.31-2).

19. As we will see, the Lockean paradigm has had a notable influence on copyright jurisprudence. See, for example, Emerson v. Davies, 8 F. Cas. 615 [C.C.D.Mass.] (1845) which argues that a person 'has a right to the copyright of a map of a state or country, which he has surveyed or caused to be compiled from existing materials, at his own expense, or skill, or labor ...' (p. 619). Other critical cases will be cited in the chapters ahead.

20. Quoted in Novak (1997), p.58. Lincoln said these words in a speech praising the US patent system.

\section{REFERENCES}

Anticybersquatting Consumer Protection Act (1999), 15 U.S.C. $§ 1125$ (d).

Barlow, John P. (1994), 'The Economy of Ideas', Wired, March, 84-6; available at: http:// www.wired.com/wired /archive/2.03/economy.ideas.html.

Borgmann, Albert (1992), Crossing the Postmodern Divide, Chicago: University of Chicago Press.

Chon, Margaret (1996), 'New Wine Bursting from Old Bottles: Collaborative Internet Art, Joint Works, and Entrepreneurship', 75 Oregon Law Review 257.

Cornish, William (2004), Intellectual Property: Omnipresent, Distracting, Irrelevant?, Oxford: Oxford University Press.

The Digital Millennium Copyright Act (DMCA), (1998) U.S.C., § 103, Title 17, § 1201 . 
Elkin-Koren, Niva (1995), 'Copyright Law and Social Dialogue on the Information Superhighway: The Case Against Copyright Liability of Bulletin Board Operators', 13 Cardozo Arts \& Entertainment Law Journal 345.

Federal Trademark Dilution Act (1996), Pub. L. No. 104-98. Codified as amended at 15 U.S.C. $\$ 1127$ (2001).

Goldstein, Paul (1991), 'Copyright', Journal of the Copyright Society of the U.S.A. 38 (1), 109-22.

Himma, Ken (2007), 'Justifying Property Protection: Why the Interests of Content Creators Usually Win over Everyone Else's', in Emily Rooksby and J. Weckert (eds.), Information Technology and Social Justice, Hershey, PA: Idea Group, pp. 47-68.

Hughes, Justin (1999), 'Recoding Intellectual Property and Overlooked Audience Interests', 77 Texas Law Review 923.

Hughes, Justin (2006), 'Copyright and Incomplete Historiographies: Of Piracy, Propertization, and Thomas Jefferson', 79 Southern California Law Review 993.

Jaffe, Adam and Josh Lerner (2004), Innovation and its Discontents, Princeton: Princeton University Press.

Kieff, F. Scott (2001), 'Facilitating Scientific Research: Intellectual Property Rights and the Norms of Science', 95 Northwestern University Law Review 691.

$\mathrm{Ku}$, Raymond (2002), 'The Creative Destruction of Copyright', 69 University of Chicago Law Review 28.

Lemley, Mark (1997), 'Romantic Authorship and the Rhetoric of Property', 75 Texas Law Review 873.

Lessig, Larry (2002), 'Free Culture: Keynote Address to Open Source Convention', published on The O'Reilly Network (http://www.oreillynet.com/pub/a/policy/2002/ 08/15/lessig.html).

Lessig, Larry (2004), Free Culture, New York: Penguin Press.

Litman, Jessica (1996), 'Revising Copyright Law for the Information Age', 75 Oregon Law Review 19.

Locke, John (1988), Two Treatises of Government, edited by Peter Laslett, Cambridge, UK: Cambridge University Press. Original work published 1698.

Macaulay, Lord Thomas (1906), 'Speech Before the House of Commons', February 5, 1841 in Lady Trevelyan (ed.), The Works of Lord Macaulay, London: Longman's Green \& Co.

Martin, Brian (1998), Information Liberation, London: Freedom Press.

Martinez, Barbara and J. Goldstein (2007), 'Big Pharma Faces Grim Prognosis', The Wall Street Journal, December 6, A1, A14.

Moglen, Eben (2002), 'Anarchism Triumphant: Free Software and the Death of Copyright', in Niva Elkin-Koren and Neil Netanel (eds.), The Commodification of Information, The Hague: Kluwer Law International, pp. 107-32.

Moglen, Eben (2003). 'Freeing the Mind: Free Software and the Death of Proprietary Culture', Keynote address delivered at University of Maine Law School (June 29); available at: http://moglen.law.columbia.edu.

Novak, Michael (1997), The Fire of Invention, Lanham, MD: Rowman \& Littlefield.

Opderbeck, D. (2004), 'The Penguin's Genome, or Coase and Open Source Biotechnology', 18 Harvard Journal of Law \& Technology 168.

Palmer, Tom (1990), 'Are Patents and Copyrights Morally Justified? The Philosophy of Property Rights and Ideal Objects', 13 Harvard Journal of Law and Public Policy 817.

'Patently Absurd' (2001), The Economist, June 23, pp.39-42. 
Perelman, Michael (2002), Steal This Idea (Intellectual Property Rights and the Corporate Confiscation of Creativity), New York: Palgrave.

Rai, Arti (1999), 'Regulating Scientific Research: Intellectual Property Rights and the Norms of Science', 94 Northwestern University Law Review 77.

Rasmussen, Douglas (2001), 'Why Individual Rights?' in T.R. Machan (ed.), Individual Rights Reconsidered, Stanford, CA: Hoover Institution, pp. 113-35.

Rifkin, Jeremy (2000), The Age of Access, New York: Putnam.

Ryan, Alan (1984), The Political Theory of Property, Oxford: Blackwell.

Shulman, Seth (1999), Owning the Future, Boston, MA: Houghton Mifflin Company.

Tushnet, Rebecca (2004), 'Copy this Essay: How Fair Use Doctrine Harms Free Speech and Copying Serves It', 114 Yale Law Journal 535.

Vaidhyanathan, Siva (2001), Copyrights and Copywrongs: The Rise of Intellectual Property and How it Threatens Creativity, New York: New York University Press.

Yen, Alfred (1990), 'Restoring the Natural Law: Copyright as Labor and Possession', 51 Ohio State Law Journal 517. 